\title{
IMPLEMENTATION OF VILLAGE FINANCIAL SYSTEM AND ITS EFFECT ON QUALITY OF FINANCIAL STATEMENTS IN JEMBER DISTRICT
}

\author{
Enita Lestine Aurriel As ${ }^{1}$ \\ Agustin HP $^{2}$ \\ Nurshadrina Kartika Sari ${ }^{3}$ \\ Higher Education of Economic Mandala \\ E-mail : enitalestine999@gmail.com
}

\begin{abstract}
This research was carried out on the basis of Law No. 6 of 2014 concerning villages, and based on an appeal letter from the Ministry of Home Affairs and KPK, in 2017 Siskeudes were introduced in 28 Sub-Districts and 226 Villages in Jember Regency, Semboro District. The population is in the research of the village government officials in Semboro District. This research used test for testing instruments, classical assumption tests and hypotheses testing. What is obtained is the driver's performance of linear regression analysis between independent variables and dependent variables simultaneously or simultaneously. The results showed the application of Siskeudes, competency of human resources, understanding of accounting, education and training, village assistance simultaneously had an effect on the quality of financial statements of $44.2 \%$. While the independent variables with independent variables show that the application of siskeudes, education and training, village assistance does not affect the quality of financial statements. Accounting understanding has a negative effect on the quality of financial statements. Human resources competencies negatively affect the quality of financial statements.
\end{abstract}

Keywords: Application Siskeudes, Quality of Financial Statements.

\section{INTRODUCTION}

Indonesian Law number 6 of 2014 about Villages explains that villages are given a great opportunity to manage their own governance, including financial management. In 2015 the Ministry of Home Affairs of the Republic of Indonesia issued Letter Number 143/8350 / BPD concerning the Village Financial Management Application, and on 31 August 2016 the Corruption Eradication Commission of the Republic of Indonesia issued a letter Number: B.7508/0116/08/2016 important with an appeal regarding Village Financial Management/ Village Funds. Research conducted by Amin and Widaninggar (2019) states that the effectiveness of the use of village funds has a significant influence on capital accumulation and empowerment of rural communities in Bondowoso Regency.

Based on a letter of appeal from the Ministry of Home Affairs and the Corruption Eradication Commission, in 
2017, the Siskeudes was introduced in all villages in Jember Regency which included 28 Districts and 226 Villages. In 2018 village financial management has begun to be implemented in all villages in Jember Regency, but the application of this application in 2018 has not been effective, because this application is still used offline and not all villages in village financial management entirely use the Siskeudes application.

Most villages only carry out a budgeting process that uses the village financial system, but there is one subdistrict in Jember Regency in 2018 that has used the Siskeudes application as a whole in the management of village finances, namely Semboro District. All villages in Semboro Subdistrict have carried out village financial management using the Siskeudes application, since the introduction of the Siskeudes Application in 2017, all village financial management reports produced have already used the Siskeudes application, hoping to produce quality financial reports.

To facilitate the village government in carrying out financial management the village government needs to implement a village financial system, in which the village financial system is a collection of interacting elements in managing village wealth. The interacting elements are expected to facilitate village government in implementing village financial management. In this study, researchers chose the Siskeudes Application, Human Resources Competence, Accounting Understanding, Education and Training and Village Assistance as part of the village financial system, which will be seen how they affect the quality of the financial statements produced.

The purpose of this study was to analyze 1) the effect of the Siskeudes application on the quality of the village financial statements partially, 2) the effect of human resource competency on the quality of the village financial statements partially, 3) the effect of accounting understanding on the quality of the village financial statements partially, 4) the influence education and training partially on the quality of village financial statements, 5) the influence of village facilitators partially on the quality of village financial reports and 6) the influence of Siskeudes application, human resource competence, accounting understanding, education and training, and village assistants on the quality of financial statements the village simultaneously.

Figure 1. Conceptual Framework

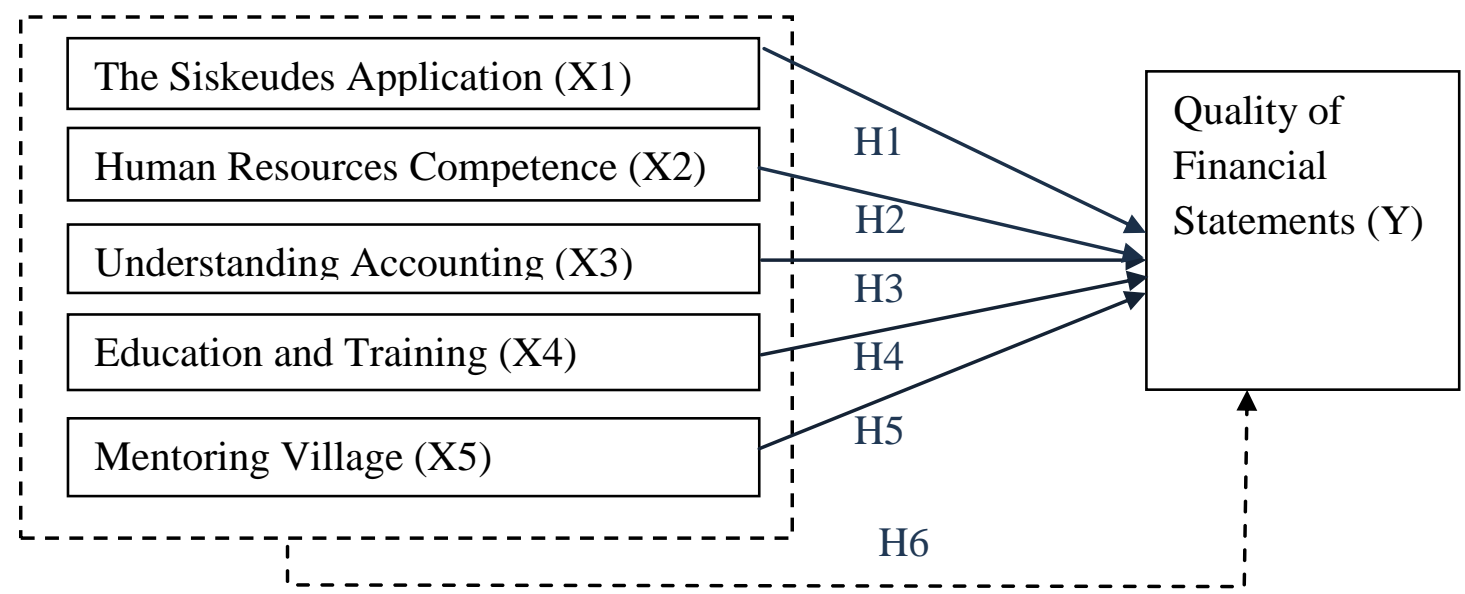

Keterangan :

$\stackrel{\longrightarrow}{\longrightarrow}$ :Influence partially

Based on Figure 1. the hypothesis of this simultaneously research are: 
H1: There is an influence of the Siskeudes application on the quality of financial statements

$\mathrm{H} 2$ : There is an influence of Human Resources Competence on the quality of financial statements.

H3: There is an influence of Accounting Understanding on the quality of financial statements.

H4: There is an influence of education and training on the quality of financial statements

H5: There is an influence of village assistance on the quality of financial statements.

H6: There is an influence of Siskeudes application, human resource competency, accounting understanding, education and training, village assistance on the quality of financial reports.

\section{RESEARCH METHODS}

\section{Research Object and Time}

The object of this study is the Village Government Apparatus located in all villages in Semboro District, Jember Regency, East Java Province. The research time was in 2019.

\section{Population and Research Samples}

The population of this study is the Village Government Apparatus in Jember Regency, with the research sample used is the entire Village Government Apparatus in the Semboro District. Where the sample selection uses a purposive sampling technique with criteria vi

\section{Variable Identification}

The research variables used in this study are the dependent variable, the Quality of Financial Statements (Y) and five independent variables, namely the Siskeudes Application (X1), Human Resources Competence (X2), Understanding Accounting (X3), Education and Training (X4) and Mentoring Village (X5).

\section{Definition of Variable Operations}

1. Quality of Financial Statements (Y) are financial statements that meet qualitative characteristics, the financial statements presented must be understandable, relevant, reliable, comparable, and full and fair disclosure.

2. The Siskeudes Application (X1) is an application created to realize clean, accountable, orderly, effective and efficient Village financial management. The indicators used are speed, safety, and economics.

3. Human Resources Competence (X2) is a person's ability to carry out one's activities, a person is able to carry out these obligations and duties, which are then used to identify the knowledge, skills, abilities and other characteristics required to carry out work adequately.

4. Understanding Accounting (X3) is to understand the components of financial statements, understand the principles of accounting, understand the recognition of elements of financial statements, understand the functions of accounting functions.

5. Education and Training (X4) is the effort of an agency to educate and train existing employees within the agency in order to increase employee knowledge, abilities, skills and expertise, which is hoped that the existence of training education conducted by an agency can improve performance and quality the employee.

6. Mentoring Village (X5) is an effort made through assistance, organization, direction and facilitation of the village.

\section{Method of Collecting Data}

Data collections by the author in this study are: Interviews, Questionnaires, Documents. Measurement of variables in this study researchers used a Likert scale instrument with a checklist form the instrument used in this study was a questionnaire. 


\section{Data Analysis Method}

Data analysis method in this study uses 1) Instrument Test in the form of validity and reliability test, 2) Descriptive statistical analysis, 3) Classical Assumptions Test namely Normality test, Multicollinearity test, Heteroscedasticity test, Autocorrelation test, 4) Multiple Linear Regression Analysis, 5) Hypothesis test using partial test (t-test) and simultaneous test (f-test) and 6) coefficient of determination $\left(\mathrm{R}^{2}\right)$.

\section{RESULT ANALYSIS}

\section{Test Instrument}

Based on the results of processing using the results of the validity test of statement items of the variable quality of the financial statements (Y), it is known that all statements are declared valid because the value of Rhitung $\geq$ from Rtable and the level of significance $\leq 0.05$

Reliability test using the Cronbach Alpha method then it is known that all variables have a Cronbach Alpha value greater than 0.70 so it can be said that the statement instruments used in this study are reliable or reliable.

\section{Descriptive Statistical Analysis}

This analysis is intended to determine the frequency distribution of respondents' answers from the list of questions distributed and contains the independent variables and the dependent variable on average the respondents answered agree and strongly agree in each question indicator.

\section{Classic Assumption Test}

a. Normality test uses the normal probability plot graph analysis method and Kolmogorov Smirnov (KS) nonparametric statistical test. Based on the results of normal graph testing the points spread around the diagonal line and the spread is not far from the diagonal line. This shows that the pattern graph is normally distributed, then the regression model meets the normality assumption, to complete the graph test, another statistical test is also performed which can be used to test residual normality, namely Kolmogorov Smirnov parametric statistical test. Testing the residual normality by using the Kolmogorov Smirnov test of 0.114 , this means a significance value $>0.05$. This means that $\mathrm{Ha}$ is rejected, Ho is accepted, which means that the residual data is normally distributed; this result is consistent with the previous test.

Table 1. Normality Test Results with Statistical Tests

One-Sample Kolmogorov-Smirnov Test

\begin{tabular}{|ll|r|}
\hline & & \multicolumn{1}{|c|}{$\begin{array}{c}\text { Unstandardized } \\
\text { Residual }\end{array}$} \\
\hline Normal Parameters ${ }^{\mathrm{a}, \mathrm{b}}$ & Mean & 60 \\
& & 0,0000000 \\
Most Extreme Differences & Std. Deviation & 1,38377204 \\
& Absolute & 0,114 \\
& & 0,114 \\
Test Statistic & Positive \\
Asymp. Sig. (2-tailed) & Negative & $-0,063$ \\
a. Test distribution is Normal. & & 0,114 \\
b. Calculated from data. & & $0,050^{c}$ \\
c. Lilliefors Significance Correction. & &
\end{tabular}


b. Multicollinearity Test shows that the tolerance value of the independent variable is Siskeudes Application variable (X1), Human Resources Competency (X2), Accounting Understanding (X3), Education and
Training (X4), Mentoring Village (X5) is value $>0.10$ while VIF results $<10$ so that from these results it can be concluded that multicollinearity does not occur.

Table 2. Multicollinearity Test Results

\begin{tabular}{|l|c|c|l|}
\hline \multicolumn{1}{|c|}{ Variabel/Item } & Tolerance & VIF & \multicolumn{1}{c|}{ Keterangan } \\
\hline Siskeudes Application $\left(\mathrm{X}_{1}\right)$ & 0,546 & 1,830 & Free Multicollinearity \\
\hline Human Resources Competency $\left(\mathrm{X}_{2}\right)$ & 0,625 & 1,601 & Free Multicollinearity \\
\hline Accounting Understanding $\left(\mathrm{X}_{3}\right)$ & 0,504 & 1,984 & Free Multicollinearity \\
\hline Education and Training $\left(\mathrm{X}_{4}\right)$ & 0,736 & 1,359 & Free Multicollinearity \\
\hline Mentoring Village $\left(\mathrm{X}_{5}\right)$ & 0,845 & 1,184 & Free Multicollinearity \\
\hline
\end{tabular}

c. Heteroscedasticity test can be seen through scatterplot graphs Based on the test results seen in the scatterplot graph that points randomly spread either above the number 0 or below the number 0 on the $\mathrm{Y}$ axis, it can be concluded that there was no heteroscedasticity.

Figure 2. Heteroscedasticity Test with Scatterplot

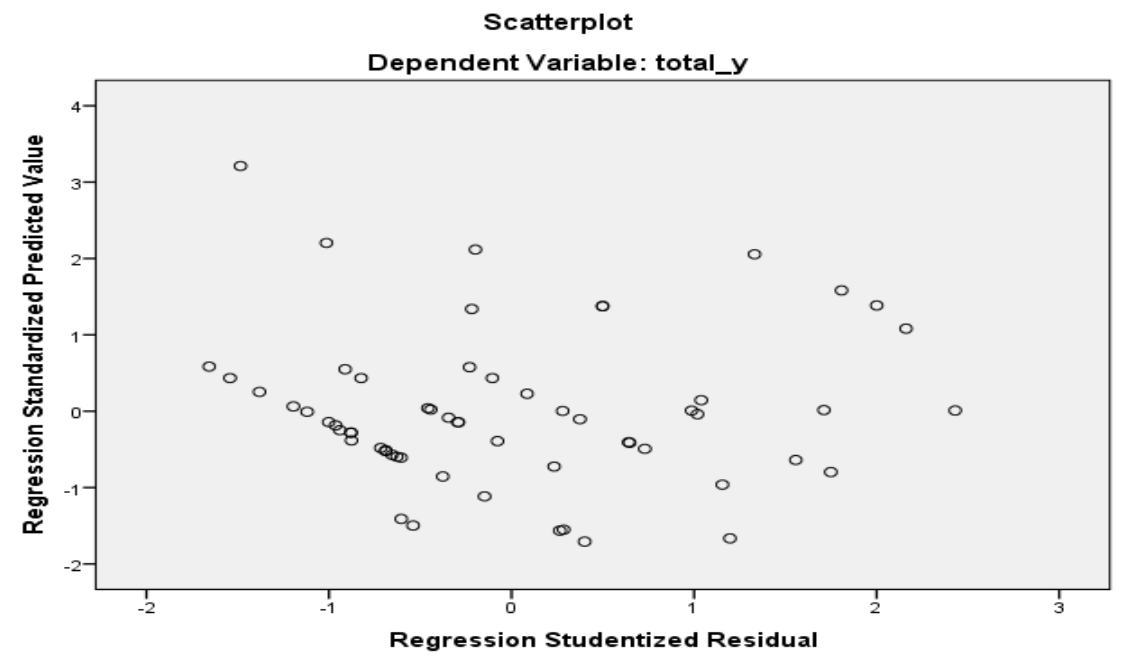

d. Autocorrelation test to detect the presence or absence of autocorrelation can use the Durbin Watson Test (DW test). Based on the results of this study it can be seen that the DW value of 2.049 will be compared to the value of the table using a significance value of $5 \%$. The number of samples is 60 and the number of independent variables is $5(\mathrm{~K}=5)$. Because the $\mathrm{DW}$ value of 2.049 is greater than the upper limit (du) 1.7671 and less than 2.2329 (4$\mathrm{du}$ ), it can be concluded that there is no autocorrelation.

Table 3. Autocorrelation Test Results after being transformed

\begin{tabular}{|c|c|c|c|c|c|}
\hline \multirow{2}{*}{$\mathrm{N}$} & \multirow{2}{*}{$\begin{array}{l}\text { Durbin } \\
\text { Watson }\end{array}$} & \multicolumn{2}{|c|}{$\mathrm{K}=5$} & \multirow{2}{*}{$4-\mathrm{dl}$} & \multirow{2}{*}{$4-d u$} \\
\hline & & $\mathrm{dl}$ & $\mathrm{du}$ & & \\
\hline 60 & 2,049 & 1,4083 & 1,7671 & 2,5917 & 2,2329 \\
\hline
\end{tabular}


4. Multiple Linear Regression Analysis

Multiple linear regression analysis was used in this study with the aim of proving hypotheses regarding the implementation of the village financial system and its effect on the quality of financial statements.

Table 4. Results of Multiple Linear Regression Analysis

Coefficientsa

\begin{tabular}{|c|c|c|c|c|c|c|}
\hline & \multirow[b]{2}{*}{ Model } & \multicolumn{2}{|c|}{ Unstandardized Coefficients } & $\begin{array}{c}\text { Standardized } \\
\text { Coefficients }\end{array}$ & \multirow[b]{2}{*}{$\mathrm{t}$} & \multirow[b]{2}{*}{ Sig. } \\
\hline & & $\mathrm{B}$ & Std. Error & Beta & & \\
\hline \multirow[t]{6}{*}{1} & (Constant) & 10,194 & 1,909 & & 5,340 & 0,000 \\
\hline & Lag_total_x1 & 0,050 & 0,101 & 0,066 & 0,495 & 0,623 \\
\hline & Lag_total_x2 & 0,448 & 0,084 & 0,640 & 5,328 & 0,000 \\
\hline & Lag_total_x3 & $-0,290$ & 0,102 & $-0,385$ & $-2,845$ & 0,006 \\
\hline & Lag_total_x4 & 0,116 & 0,067 & 0,200 & 1,716 & 0,092 \\
\hline & Lag_total_x5 & 0,056 & 0,094 & 0,069 & 0,603 & 0,549 \\
\hline
\end{tabular}

a. Dependent Variable: Lag_total_y

Based on the analysis results in Table 4, the regression equation can be obtained, namely:

$\mathrm{Y}=10.194+0.050 \mathrm{X} 1+0.448 \mathrm{X} 2-0.290 \mathrm{X} 3$ $+0.116 \mathrm{X} 4+0.056 \times 5$

The regression equation above can be explained as follows:

a. The value of the constant is positive 10.194 which means it shows the magnitude of the Quality of Financial Statements when the Siskeudes Application, Human Resources Competency, Accounting Understanding, Education and Training, Village Assistance are zero.

b. The regression coefficient value of the Siskeudes Application (X1) value is 0.050 with a positive sign that indicates if the use of the Siskeudes Application (X1) in all Semboro sub-villages is optimized, the financial reports produced by the village government will produce quality financial reports.

c. The regression coefficient value of the Human Resources Competency variable (X2) is 0.448 with a positive sign which indicates that if the Human Resources
Competency increases, the quality of the resulting Financial Statements will be better.

d. The regression coefficient value of the Accounting Understanding variable (X3) is -0.290 with a negative sign which indicates that if the Accounting Understanding (X3) is increased it will cause a decrease in the Quality of Financial Statements. Score

e. The regression coefficient of the Education and Training variable (X4) is 0.116 with a positive sign which indicates that if Education and Training continues to be improved, the Quality of Financial Reports produced will be better.

f. The regression coefficient value of the Village Assistance (X5) value is 0.056 with a positive sign which indicates that if the Village Assistance (X5) continues to be improved, the Quality of Financial Reports produced will increase, if each village in the Semboro District continues to be accompanied by assistants, the quality of the report finances generated by the village will be better. 


\section{Hypothesis Testing}

Table 5. Recapitulation of Hypothesis Test Results

\begin{tabular}{|l|c|c|}
\hline \multicolumn{1}{|c|}{ Variabel Independen } & P-Value & Hasil Uji Hipotesis \\
\hline Siskeudes Application $\left(\mathrm{X}_{1}\right)$ & 0,623 & Ho accepted \\
\hline Human Resources Competency $\left(\mathrm{X}_{2}\right)$ & 0,000 & Ho rejected \\
\hline Accounting Understanding $\left(\mathrm{X}_{3}\right)$ & 0,006 & Ho rejected \\
\hline Education and Training $\left(\mathrm{X}_{4}\right)$ & 0,092 & Ho accepted \\
\hline Mentoring Village $\left(\mathrm{X}_{5}\right)$ & 0,549 & Ho accepted \\
\hline
\end{tabular}

Table 6. Simultaneous Test Results

\begin{tabular}{|l|r|r|r|r|r|}
\hline Model & Sum of Squares & Df & Mean Square & F & Sig. \\
\hline 1 Regression & 78,376 & 5 & 15,675 & 8,385 & $0,000^{\mathrm{b}}$ \\
Residual & 99,083 & 53 & 1,869 & & \\
Total & 177,459 & 58 & & & \\
\hline
\end{tabular}
a. Dependent Variable: Lag_total_y
b. Predictors: (Constant), Lag_total_x5, Lag_total_x2, Lag_total_x1, Lag_total_x4,

Lag_total_x3

Hypothesis test results can be interpreted as follows:

a. Siskeudes Application Variable (X1) does not partially affect the Quality of Financial Statements (Y).

b. Human Resources Competency Variable (X2) partially influences the Quality of Financial Statements (Y).

c. Accounting Understanding Variable (X3) partially affects the Quality of Financial Statements (Y).

d. The Education and Training Variable (X4) does not partially affect the Quality of Financial Statements (Y).

e. Village Companion Variable (X5) does not partially affect the Quality of Financial Statements (Y).

f. Siskeudes Application Variable (X1), Human Resources Competency Variable (X2), Accounting Understanding Variable (X3), Education and Training Variable (X4) and Village Companion Variable (X5) simultaneously affect the Quality of Financial Statements (Y).

\section{Coefficient of Determination (R2)}

Table 7. Determination Coefficient Results

\begin{tabular}{|l|c|r|r|r|r|}
\hline \multicolumn{1}{|c|}{ Model $^{\text {Model Summary }}$} \\
\hline 1 & $\mathrm{R}$ & $\mathrm{R}$ Square & $\begin{array}{l}\text { Adjusted R } \\
\text { Square }\end{array}$ & $\begin{array}{c}\text { Std. Error of the } \\
\text { Estimate }\end{array}$ & Durbin-Watson \\
\hline $1665^{\mathrm{a}}$ &, 442 &, 389 & 1,36730 & 2,049 \\
\hline
\end{tabular}

a. Predictors: (Constant), Lag_total_x5, Lag_total_x2, Lag_total_x1, Lag_total_x4,

Lag_total_x3

b. Dependent Variable: Lag_total_y

Based on table 4.26 obtained a regression model with a correlation coefficient $(\mathrm{R})$ of 0.665 , the coefficient of

determination (R-Square) of 0.442 means that the ability of the model to explain the 
variation of the dependent variable by $44.2 \%$.

\section{INTERPRETATION}

The interpretation of this study is explained as follows:

1. The Effect of Siskeudes Application on the Quality of Financial Statements partially

The results of this study indicate that the Siskeudes application has no effect on the quality of financial statements. The Siskeudes application has been implemented in all villages in Semboro District. Utilization of this application has not been maximized; the apparatus in charge on average are still high school graduates. The results of this study are not in line with Puspasari and Purnama (2018) which shows that the Competency of Human Resources (HR) and the use of information technology strengthen the influence of the implementation of the village financial system on the quality of financial statements.

2. The effect of Human Resources Competence partially on the Quality of Financial Statements

Human Resources Competence has a positive effect on the Quality of Financial Statements; this is because the village government apparatus is able to implement village financial governance properly. It is also supported by work experience of more than five years. The results of this study are in line with research conducted by Setyowati et al (2016) who found that the quality of human resources has a significant influence on the quality of the Regional Government Financial Statements and Nurillah (2014) research findings found that the quality of human resources has a positive and significant influence on the quality of financial statements.
3. The Effect of Accounting Understanding on the Quality of Financial Statements partially

Accounting understanding negatively affects the quality of financial statements. The village government apparatus already understood the evidence of the transaction but still could not explain it again at the time of the interview, who truly understood only a few people. This is not in line with research conducted by Yuliani et al. (2010) where the results of this study state that accounting understanding has a positive effect on the quality of financial statements, in research conducted by yuliani, selecting populations that are accounting entities within the Banda Aceh City government total 35 SKPD with the criteria have compiled 2008 financial statements.

4. The Effect of Education and Training on Partial Quality of Financial Statements

Education and training does not affect the quality of financial statements, this is because the average level of education is still a high school graduate and the training is still very small. This result is not in line with the results of a study conducted by Muzahid (2014) where partially the level of education, quality of training, and length of work experience of each employee had a positive effect on the quality of financial statements of regional work units (SKPD).

5. The Effect of Village Companions on the Quality of Financial Statements partially

The results of this study indicate that Village Assistance does not affect the Quality of Financial Statements, this is because the assistants are still able to master about the village and about financial management in the village, so that the assistants have difficulty in organizing, facilitating and assisting villages. In addition, village facilitators 
have not been maximized in making an emotional approach to the village government apparatus, and establishing good communication. The results of this study are not in line with Pahlavi (2017) who found that village facilitators had authority in planning programs, utilization, and supervision of Village Fund Allocation. In addition, the results of the study by Wiguna et al (2017) found that village facilitators had an effect on the successful application of the Siskeudes application. With the village assistance provided by the village facilitators it is hoped that it can produce quality financial reports.

6. The Influence of Siskeudes Application, Human Resources Competence, Accounting Understanding, Education and Training, Village Facilitation simultaneously influence the Quality of Financial Statements

The results of this study indicate that the application of Siskeudes, Competence of Human Resources, Understanding of Accounting, Education and Training, Village Facilitation simultaneously influence the Quality of Financial Statements. If all the independent variables in this study are improved it will produce a quality financial report.

\section{CONCLUSION}

Based on the results of the analysis and interpretation of the research that has been presented previously, the authors obtain the conclusions that can be drawn in this study are as follows:

1. The Siskeudes application does not have a significant effect on improving the quality of village government financial reports in Semboro District.

2. Human Resources Competence has a positive and significant impact on improving the quality of village government financial reports in Semboro District.
3. Accounting understanding has a negative and significant impact on improving the quality of village government financial reports in Semboro District.

4. Education and training does not have a significant effect on improving the quality of village government financial reports in the Semboro sub-district.

5. Village assistance does not have a significant effect on improving the quality of village government financial reports in the Semboro sub-district.

6. Application of Siskeudes, Competence of Human Resources, Understanding of Accounting, Education and Training and Village Assistance together (simultaneously) have a significant effect on improving the quality of village government financial reports in Semboro District

\section{IMPLICATION}

The village government needs to pay attention to the following things so that in village financial management it can produce good quality financial reports. The use of the Siskeudes Application is enhanced, by paying attention to the Competency of Human Resources, the level of education and suitability of the departments operating the Siskeudes Application.

Human Resources Competence in village government is good, the village government needs to maintain, and increase the knowledge, skills and abilities of village government officials, with improved education and training efforts.

All village government apparatuses need to understand accounting, in this study there are only $20 \%$ of village government apparatuses who understand accounting, if all village government apparatuses understand accounting make it easier for village officials in managing village finances, because all village officials understand and can be accountable for reports village finance. 
Village facilitation by assistants must be further improved, after the village government apparatus participates in training at the Regency / City level, it is better for the facilitator to provide facilitation or training to the village government to deepen their knowledge of the results of the training that was followed at the Regency / City level, as well as assistance to the use of the Siskeudes Application is increased, so that the village government masters the use of the application.

\section{REFERENCES}

Amin, S., \& Widaninggar, N. (2019). Influence of Village Funds on Capital Accumulation and Community Empowerment. Economics Development Analysis Journal, 8(2), 163-173. https://doi.org/10.15294/edaj.v8i2.27 508

Muzahid, Mukhlisul, 2014, Pengaruh Tingkat Pendidikan, Kualitas Pelatihan, Dan Lama Pengalaman Kerja Pegawai Terhadap Kualitas Laporan Keuangan Satuan Kerja Perangkat Daerah (SKPD) di kabupaten Aeh Utara, Vol 2, 179196, Jurnal, Politekhnik Negeri Lhoukseumawe.

Nurillah, As Syifa, 2014, Pengaruh Kompetensi Sumber Daya Manusia. Penerapan Sistem Akutansi Keuangan Daerah (SAKD), Pemanfaatan Tekhnologi Informasi Dan Sitem Pengendalian Intern Tehadap Kualitas Laporan Keuangan Pemerintah Daerah (Study Empiris Pada SKPD Kota Depok), Skripsi, Universitas Diponegoro.

Pahlevi, Reza, 2017, Kewenangan Pendamping Desa Dalam Rangka Penyelenggaraan Pemerintah Desa (Studi Di Desa Pugung Raharjo Kabupaten Lampung Timur), Skripsi, Universitas Lampung.

Puspasari, Oktaviani Rita Dan Purnama, Dendi, 2018, Implementasi Sistem
Keuangan Desa Dan Kualitas Laporan Keuangan Pemerintah Desa Di Kabupaten Kuningan, Vol, 2, 145159, Jurnal, Universitas Kuningan.

Setyowati, dkk, 2016, Faktor - Faktor Yang Mempengaruhi Kualitas Laporan Keuangan Pemerintah Daerah Kota Semarang, Vol 20, 179-191, Jurnal, Univesitas Dian Nuswantoro.

Wiguna, dkk, 2017, Pengaruh Kualitas

Sumber Daya Manusia, Pendidikan Dan Pelatihan, Serta Peran Pendamping Desa Terhadap Efektivitas Penggunaan Sistem Keuangan Desa (Siskeudes) (Studi Pada Desa Penerima Dana Desa Di Kabupaten Buleleng), Vol 8, Jurnal, Universitas Pendidikan Ganesha.

Yuliani, dkk, 2010, Pengaruh pemahaman akuntansi, pemanfaatan sistem informasi akuntansi keuangan daerah, dan peran internal audit terhadap kualitas laporan keuangan pemerintah daerah (study pada pemerintah kota banda aceh), Vol 3, 206-220, Jurnal, Universitas Syiah Kuala.

Undang Undang Republik Indonesia, Nomor 6, Tahun 2014 Tentang Desa.

Peraturan Menteri Desa, Pembangunan Daerah Tertinggal, dan Transmigrasi Republik Indonesia Nomor 3, Tahun 2015, Tentang Pendampingan Desa.

Setyowati, dkk, 2016, Faktor - Faktor Yang Mempengaruhi Kualitas Laporan Keuangan Pemerintah Daerah Kota Semarang, Vol 20, 179-191, Jurnal, Univesitas Dian Nuswantoro.

Surat Edaran Kementerian Dalam Negeri Nomor 143/8350/BPD, Tahun 2015 Tentang Aplikasi Pengelolaan Keuangan Desa.

Surat Edaran Komisi Pemberantasan Korupsi Nomor B.7508/0116/08/2016, Tahun 2016 Tentang Himbauan Terkait Pengelolaan Keuangan Desa/Dana Desa. 